\title{
ENFORCING THE OCCUPATIONAL SAFETY AND HEALTH ACT OF 1970: THE FEDERAL GOVERNMENT AS A CATALYST
}

\author{
JOHN H. STENDER*
}

\section{INTRODUCTION}

The national debate surrounding the federal government's role in enforcing an occupational safety and health program has produced a number of widely differing views. On the one hand, the government has been accused of insufficient effort, given the magnitude of the problem; on the other hand, it has been charged with using an unconstitutional law to bludgeon employers into making unnecessary expenditures. Actually, the federal government conceives of its role in administering and enforcing the Occupational Safety and Health Act of $1970^{1}$ quite differently than either of these two views. The most apt description of the federal viewpoint is that government is a catalyst-a catalyst with the expressed desire to achieve a safe and healthful work environment by voluntary means.

The Occupational Safety and Health Act was designed to bring the resources and commitment of the federal government to bear on the problem of work-related deaths, injuries, and illnesses. The increasing growth and complexity of modern industry, with its sophisticated work processes and cascade of new materials, were resulting in the deaths of more than 14,000 workers and disabling injuries to more than two million others in the years immediately preceding passage of the Act. ${ }^{2}$ The magnitude of this tragedy can be seen by comparing the employment-related mortality rate with that of the U.S. forces in Vietnam. During the two years preceding the Act's passage, the number of workplace deaths was more than twice that of battlefield fatalities. In addition to the needless human suffering involved, this workplace toll constituted a significant drain on the resources of the country. Lost wages exceeded $\$ 1.5$ billion a year and the total workmen's compensation cost to employers was $\$ 4.82$ billion in 1970 alone. $^{3}$

By the middle of the last decade it was apparent that the efforts of those concerned with this problem-state legislatures, industry and its safety specialists, and labor unions-had not decreased the workplace toll. Historically, safety and health legislation had been left to the states, but their response was uneven. A few states, notably New York, Pennsylvania, and California, had adequate job safety laws. Many others either had legislation which covered only particular industries or had devoted insufficient resources to the situation.

\footnotetext{
*Assistant Secretary of Labor for Occupational Safety and Health, U.S. Department of Labor.

129 U.S.C. $\$ \S 651-78$ (1970).

2 National Safety Council, Accident Facts (1972).

3 U.S. Dep'T OF Labor, The President's Report on Occupational Safety and Health 1 (1972).
} 
Some safety inspectors were chosen for political allegiance rather than professional experience. Occupational health was often misunderstood or ignored completely. Even where effective state regulation was attempted, it was necessarily limited by state boundaries. When Pennsylvania banned the manufacture, use, and storage of the chemical betanaphthylamine, an extremely hazardous substance linked with cancer of the bladder, the manufacturer moved its plant to Georgia, which did not then regulate the chemical. Industry's response was similarly ineffectual. Many large manufacturers had developed programs designed to create employee awareness of safe work habits while minimizing administrative or engineering control of the hazards. Few of these programs even considered the deleterious effects of toxic substances, partly because of the long studies necessary to prove a correlation between a substance and its effect on those exposed to it.

The legislative history of the Act reflects these previous failures as well as a congressional desire for a multifaceted approach to the problem. In Senate discussions of the bill, Senator Harrison A. Williams, Jr. of New Jersey, sponsor of the bill, stated:

Although many employers in all industries have demonstrated an exemplary degree of concern for health and safety in the workplace, their efforts are too often undercut by those who are not so concerned. Moreover, the fact is that many employers-particularly smaller ones-simply cannot make the necessary investment in health and safety, and survive competitively, unless all are compelled to do so. The competitive disadvantage of the more conscientious employer is especially evident where there is a long period between exposure to a hazard and manifestation of an illness. In such instances, a particular employer has no economic incentive to invest in current precautions, not even in the reductions of workmen's compensation costs, because he will seldom have to pay for the consequences of his own neglect.

Nor has state regulation proven sufficient to the need. No one has seriously disputed that only a relatively few States have modern laws relating to occupational health and safety and have devoted adequate resources to their administration and enforcement. Moreover, in a State-by-State approach, the efforts of the more vigorous states are inevitably undermined by the shortsightedness of others.

In sum, the chemical and physical hazards which characterize modern industry are not the problem of a single employer, a single industry, nor a single state jurisdiction. The spread of industry and the mobility of the workforce combine to make the health and safety of the worker truly a national concern. ${ }^{4}$

In the House of Representatives, Congressman William A. Steiger of Wisconsin expressed the intent of the legislation he sponsored (which was combined with the Williams bill to create the Act):

One of the primary purposes of the bill is to set up a mechanism by which fair and effective occupational safety and health standards can be promulgated so that the many employers and employees throughout the Nation may be guided in their attempts to establish and maintain safe and healthful work environments.

The conference reported bill is clearly based on the premise of this House

\footnotetext{
${ }^{4}$ Subcomm. on labor of the Senate Comm. on Labor and Public Welfare, 92d Cong., 1st Sess., Legislative History of the Occupational Safety and Health Act of 1970, at 413 (Comm. Print 1971).
} 
that it is with the cooperation of both employers and employees that the Act can most effectively meet the challenge of reducing and perhaps eliminating most of the occupational deaths, tragic injuries, and diseases which take a large annual toll in terms of the human suffering and loss to the economy caused by these tragedies. ${ }^{5}$

\section{Administration of the Act}

The Act, which is administered by the U.S. Department of Labor's Occupational Safety and Health Administration (OSHA), not only provides for strong enforcement authority, but also emphasizes improving the work environment by a combination of voluntary compliance, research, training, and education. ${ }^{6}$ OSHA thus has an obligation to stimulate awareness not only of workplace deaths, injuries, and illnesses, but of solutions to those problems. This obligation has been translated into a workable program in the administration of the Act. The thrust of that program was presented by President Nixon in a report to Congress in May, 1972.

Like many problems that we face today, the improvement of job safety and health cannot be accomplished by simply pressing a button. If we are to reduce the injuries, the illnesses, and the deaths connected with working conditions we must increase the number of people who are trained in health and safety techniques; knowledge of the cause of accidents and illness must be developed; this knowledge must be translated into effective standards; employers and employees require adequate instructions; and standards must be enforced through energetic and rigorous inspection programs.

Above all else, if we are to be successful, the full collaboration of private industry, the States, and the employee must be enlisted. ${ }^{7}$

The federal government's attempt to act as a catalyst ${ }^{8}$ for the various sectors of society in the task of reducing workplace tragedies is apparent in the manner in which the major mandates of the Act have been administered.

\section{A. Adoption of Standards}

The Act directed OSHA to promulgate by rule as its own standards any existing national consensus standards and any established federal standards,

\footnotetext{
${ }^{5}$ Id. at 1216 .

${ }^{6}$ The law is prefaced as follows:

An Act to assure safe and healthful working conditions for working men and women; by authorizing enforcement of the standards developed under the Act; by assisting and encouraging the States in their efforts to assure safe and healthful working conditions; by providing for research, information, education, and training in the field of occupational safety and health; and for other purposes.

Congress declared its intention to preserve the country's human resources by encouraging private efforts and voluntary measures. Section 2 of the Act, 29 U.S.C. $\$ 651$ (1970), places initial emphasis upon actions by employers and employees to implement safety practices and procedures which are currently recognized in the industry and which are continually being developed by the private and public sectors. Further, OSHA is vested with the authority to set and enforce mandatory occupational safety and health standards. Other provisions of the Act serve to stimulate activities to preserve safety and health.

7 U.S. DEP'T OF LABOR, supra note 3, at iii.

${ }^{8}$ OSHA's organizational structure reflects this role. An Office of Training and Education, an Office of State Plan Review and Evaluation, and a Division of Voluntary Compliance Program-
} 
except those already covered under other legislation in such fields as mining and atomic energy. Under that mandate, OSHA formally promulgated an initial package of standards upon coming officially into existence on April $28,1971 .^{9}$ This package incorporated verbatim or by reference pertinent standards previously adopted by such national consensus standards-setting organizations as the American National Standards Institute (ANSI), the National Fire Protection Association (NFPA), and the American Society for Testing and Materials (ASTM). There were also included standards derived from six other existing federal acts. ${ }^{10}$

For the first two years of its existence, OSHA was authorized to promulgate standards by rule alone. ${ }^{11}$ This procedure was designed to expedite development and issuance of standards in the interest of providing the fastest and broadest possible initial coverage of employees. Since April, 1973, standard development has required a more deliberate procedure including, if OSHA determines it to be pertinent, the appointment of advisory committees composed of representatives of management, labor, safety and health professionals, state agencies, the National Institute for Occupational Safety and Health (NIOSH), and the public. ${ }^{12}$ Standards Advisory Committees have been established for such areas as agriculture, construction, noise, and asbestos. OSHA also can hold public hearings if requested by interested parties, who can either appear personally or submit written statements.

The research and medical criteria needed to increase knowledge of the causes and remedies for both safety and health hazards are to be provided by NIOSH. ${ }^{13}$ Among the responsibilities of that agency are safety and health research, an annual listing of toxic substances (now numbering more than 15,000), and manpower development and training. Its most important research is that which produces criteria for standards for toxic materials and harmful physical agents. OSHA uses these criteria as a basis for proposing standards. NIOSH is also involved in the compilation of safety and health statistics, dissemination of technical information, and employer-employee educational efforts.

The NIOSH research has assumed greater importance as OSHA has focused on the exceedingly complex but critical task of identifying and elim-

\footnotetext{
ming are all engaged in encouraging employers and employees to comply voluntarily with OSHA's standards.

${ }^{9}$ See 29 C.F.R. $\$ \S 1910,1915-18,1926$ (1972). See generally id. \$§ 1900-2200. These initial standards were revised and updated late in 1972. See id. $\S \S 1910.1-.309,1915.1-.111,1926.1-$ $.57,1926.100-.1051$. Recently the standards were further clarified and updated. See 1 Occ. Safety \& Health Subscription Serv., General Industry Standards and Interpretation change 1 (Sept. 27, 1973).

${ }_{10}$ See Walsh-Healy Public Contracts Act of 1936, 41 U.S.C. $\$ \S 35-45$ (1970); Service Contract Act of 1965, 41 U.S.C. $\$ \S 351-57$ (1970); Contract Work Hours and Safety Standards Act, 40 U.S.C. $\$ \$ 327-33$ (1970); Longshoremen's and Harbor Workers' Compensation Act $\$ 41$, 33 U.S.C. \$ 941 (1970), formerly ch. 509, §41, 44 Stat. 1444 (1927); National Foundation on the Arts and Humanities Act of $1965 \S 5(j), 20$ U.S.C. \$ 954(i) (1970); 5 U.S.C. \& 7902 (1970) (mandating that federal safety programs be instituted).

${ }^{11}$ Occ. Safety \& Health Act $\$ 6(a), 29$ U.S.C. $\$ 655(a)$ (1970).

${ }^{12}$ Id. $\S 6(\mathrm{~b})(1), 29$ U.S.C. $\S 655(\mathrm{~b})(1)$.

${ }^{13} I d$. $\$ \S 20,22,29$ U.S.C. $\$ \S 669,671$. NIOSH is a companion agency to OSHA within the Department of Health, Education, and Welfare.
} 
inating toxic substances in the workplace. One of the main reasons for the failure of previous private and governmental attempts at correcting this situation was their inability to grasp the scope of the problem. Both the number and toxicity of thousands of substances used in the workplace were little understood. NIOSH has enabled OSHA to begin to understand the magnitude of the task of identifying these hazards.

To recapitulate, regardless of the procedure used to set a particular standard, OSHA insists on the fullest possible participation by all interested parties, particularly those directly affected. Not only does this provide an opportunity for ventilating all opinions, it also assures standards that will be the most accurate and practical for employee protection.

\section{B. Enforcement of Standards: Inspection and Citation Procedure}

The current federal role in workplace protection is most clearly distinguished from previous governmental efforts by its enforcement capability. The Act authorized OSHA compliance officers (inspectors) to make unannounced inspections of virtually any establishment. ${ }^{14}$ The rationale for this provision is that if employers received advance notice of an inspection, they would tend to make cosmetic corrections of hazardous conditions, which result in no more than momentary protection for employees. Congress considered this possibility so serious that it wrote into the Act a requirement that anyone giving advance notice of an inspection without authority from OSHA will, if convicted, be fined up to $\$ 1,000$, imprisoned for up to six months, or both. ${ }^{15}$

Despite widespread erroneous allegations, OSHA inspectors cannot "impose huge fines on the spot." Rather, the actual procedure for enforcing standards begins with selection of establishments to be inspected in accordance with a set of priorities, since OSHA could not possibly simultaneously inspect every one of the five million establishments it covers. ${ }^{16}$ Before starting on an assigned inspection, the compliance officer does his homework as to the kind of workplace or product involved, the types of hazards he might expect to find, and whether he will need certain types of equipment to test air, noise, toxic substances, and so on. ${ }^{17}$ Upon entering the establishment, he presents

\footnotetext{
${ }^{14} I d . \S 8(\mathrm{a}), 29$ U.S.C. $\$ 657(\mathrm{a})$.

${ }^{15}$ Id. $\$ 17(\mathrm{f}), 29$ U.S.C. $\$ 666(\mathrm{f})$.

${ }^{16}$ The current priorities are: (1) situations of imminent danger in the workplace (the venting of toxic fumes, an improperly shored construction trench, or excavation on the verge of collapse, for example); (2) fatalities and catastrophies (which result in hospitalization of five or more employees); (3) valid employee complaints; (4) special emphasis programs such as the Target Industry Program which involves five industries with injury frequency rates more than double the national all-industry average (longshoring, roofing and sheet metal, lumber and wood products, manufacture of miscellaneous transportation equipment such as mobile homes and snowmobiles, and meat and meat packing), the Target Health Hazards Program which involves five of the major toxic substances in industry (asbestos, carbon monoxide, cotton dust, lead, and silica), and a program on cave-ins in construction trenching and excavation operations; and (5) random selection of all types and sizes of establishments all over the country. See U.S. DEP'T OF LABOR, All about OSha: The Who, What, Where, When, Why and How of the Occupational Safety and Health Act of 1970, at 9 (OSHA Pub. No. 2056, 1973).

${ }^{17} \mathrm{Id}$. at 11 .
} 
his credentials, confers with the designated management representative regardirig the procedure and scope of the inspection, checks whether the OSHA poster is displayed, looks over the establishment's safety and health record, then asks that an employee representative join him and the management representative on a walkaround inspection. At the subsequent closing conference, the inspector informs the employer of what he has noted and asks the manager's estimate of a reasonable time to abate any hazards. The inspector then returns to his office and sends his report to his Area Director, who analyzes the information and issues any citations and proposes any penalties.

OSHA cannot impose penalties, it can only propose them. If an employer does not contest a citation and proposed penalty within the prescribed fifteen working days, then the OSHA action becomes a final order of the Occupational Safety and Health Review Commission. ${ }^{18}$ If an employer does file a timely notice of contest, then the case moves to the Review Commission, a wholly independent three-member panel not associated with the Department of Labor or OSHA. ${ }^{19}$ Before that point is reached, however, OSHA conducts informal conferences with the employer in an effort to resolve problems (particularly of employer misunderstanding or unawareness of various aspects of the Act or the agency's implementation of it) in the interest of expediting worker protection through voluntary compliance.

When a case goes to the Review Commission (as have about five per cent of all cases to date), it is assigned to an administrative law judge who sets a hearing as near as possible to the employer's place of business. The employer need not be represented by counsel, and many are not. If the employer or the Review Commission is dissatisfied with the administrative law judge's decision, the full three-member Commission will review the case. The Commission makes its decision on the record of the case; it has held only two oral hearings since its creation and has indicated it does not plan others. Should either the employer or the Department desire, Review Commission decisions may be appealed to a federal court of appeals.

To summarize, inspections have as their objective improved conditions in the workplace. In part, this objective is obtained by a multiplier effect-an inspection of an establishment in a particular industry will usually produce voluntary compliance activity by other employers in that industry. This ripple effect cannot be quantified, but its impact is apparent. For example, employers in the nation expect to spend $\$ 3.03$ billion to improve employee safety and health in 1975, up eighteen per cent from the $\$ 2.6$ billion invested in 1973 . By 1977 , industry estimates it will be spending $\$ 3.44$ billion, an increase which cannot be wholly laid to inflation. ${ }^{20}$ The ultimate value of an inspection thus can be found not in its punitive effect, but rather in its deterrent effect. If not faced with the possibility of an inspection, employers would lose much of their motivation for achieving the goals of the Act.

\footnotetext{
${ }^{18}$ Occ. Safety \& Health Act \& 10(a), 29 U.S.C. § 659(a) (1970).

19 Id. $\$ 12,29$ U.S.C. $\$ 661$.

20 D. Greenwald, Second annual McGraw-Hill Survey in Employee Safety and Health (1974).
} 
II

\section{The Federal Government as a Catalyst in Occupational SafETy and Health}

\section{A. The Roles of Labor and Management}

In fulfilling the Act's directive to encourage employer and employee efforts, OSHA has realized tangible results. Labor unions are instructing their members on their rights and responsibilities under the law. Among the 116 unions affiliated with the AFL-CIO, for example, there are more than thirtyfive full-time safety and health directors and several others devoting at least part of their time to this issue. Many of them were appointed after passage of the Act. The Industrial Union Department of the AFL-CIO has created a new Department of Health, Safety, and Environmental Affairs to supply information, research, and educational materials to the fifty-nine IUD-affiliated unions, all of which have named at least a part-time safety and health director. The United Steelworkers' summer institute now devotes several hours of each day to instructing members on the law. Thirteen unions are cooperating with OSHA in training courses developed under a contract with the University of Wisconsin.

The business sector has initiated voluntary compliance efforts in many areas. Trade associations are pinpointing relevant standards for their members; several industries, such as telecommunications and textiles, have submitted suggested standards governing workplace conditions in their member firms. Larger industrial groups, such as the National Association of Manufacturers and the United States Chamber of Commerce, have developed large-scale informational efforts for their members.

One place where employer and employee activities come together is at the collective bargaining table when safety and health provisions are included in contracts. Such provisions have appeared frequently since the Act was signed. The president of the Oil, Chemical, and Atomic Workers Union (AFL-CIO) has stated that the Act helped make it possible for his union and the major oil companies to deal effectively with job safety and health problems in that industry. In 1973, the International Brotherhood of Teamsters and the National Automobile Transporters concluded an agreement to assure safe and healthy employment conditions for employees in that field. Even more significant was a contract signed in 1973 by the Chrysler Corporation and the United Auto Workers (UAW). This agreement detailed specific measures to be taken to protect the safety and health of UAW members employed by Chrysler. It represented the first time in the history of the automobile industry that such a comprehensive program had been negotiated. Similar contracts were concluded by the UAW. with the General Motors Corporation and the Ford Motor Company.

\section{B. OSHA Training Programs}

OSHA also builds upon advances already made through employer-employee initiative by formal and informal contacts with the public. These include sem- 
inars conducted by OSHA field personnel, speeches given by both national office and field staff, numerous publications designed to aid employers and employees in complying with the law, and cooperative programs with trade associations and unions. Within OSHA's organization are many safety professionals formerly employed by industry, who lend their expertise and experience to OSHA-industry cooperation.

Congress was aware of the paucity of trained specialists in occupational safety and health, so it provided in the Act for training programs to increase the number of such professionals. This resulted in the establishment of the OSHA Training Institute near Chicago which instructs federal and state compliance officers and offers free instruction to labor and industry representatives. The National Safety Council, under contract with OSHA, is providing training for business establishments with fewer than 500 employees.

\section{The Role of the States}

One of the important and controversial components of the Act encourages states to develop and administer their own occupational safety and health programs. ${ }^{21}$ At issue is the historical position of the states in this area. The Act was a response to state inadequacies, but if the states are willing and able to assume responsibility for protection of their work force, the federal government will aid them by example and by substantial funding. The key condition requires that the states assure OSHA that their programs will be at least as effective as the federal program in providing safe and healthful places of employment. Eight criteria for approval are included in the law, mandating not only standards which are as effective as federal standards, but also right of entry for inspectors, a ban on advance notice of inspections, sufficient legal authority for the enforcing agency, adequate funding, coverage of public employees to the extent permitted by state law, and adequate reporting procedures. ${ }^{22}$

Opponents of state programs contend that the states historically proved inadequate to the task and should remain precluded from responsibility for workplace conditions. They advocate a complete federal presence throughout the nation in workplace safety and health because the Act and OSHA's regulations regarding state plans provide insufficient protection for return of this authority to the states.

These observers neglect the myriad advantages inherent in sharing this program with the states. The enforcement effort is multiplied and remains effective since the federal government, which pays fifty per cent of the operating costs of state programs, continues to monitor their effectiveness closely. If at any time a state fails to comply with provisions of its approved plan, or fails to make necessary changes as the federal-state partnership evolves, OSHA can withdraw its approval. Additional advantages of a joint federal-state occupational safety and health effort include: the addition of state manpower and funding, programs designed to suit the unique circumstances of workplace conditions in individual states, an opportunity for the states to regain some

\footnotetext{
${ }^{21}$ Occ. Safety \& Health Act $\S 18,29$ U.S.C. $\S 667$ (1970).

22 Id. \& 18(c), 29 U.S.C. $\S 667(\mathrm{c})$.
} 
of the prerogatives lost to Washington in recent decades (providing a laboratory for the effectiveness of governmental decentralization), and the only opportunity to protect employees of state and local governments since such employees are otherwise excluded from the Act's coverage.

Forty-six states and other jurisdictions (such as the Virgin Islands, Guam, Puerto Rico, American Samoa, and the District of Columbia) have submitted plans for resuming operation, twenty-six of which have been approved. Only six states have not submitted such proposals and four more have withdrawn their plans. ${ }^{23}$ In those areas, full federal enforcement will continue indefinitely.

\section{Protection for Federal Employees}

While the Act defines "employer" in terms excluding the federal government, ${ }^{24}$ it also requires the head of each federal agency to establish a safety and health program that is consistent with the OSHA program. ${ }^{25}$ In enforcing the law, the federal government has been cognizant of its responsibility for the physical well-being of its own employees. An Executive Order charges each department and agency with the responsibility of establishing an occupational safety and health program consistent with standards prescribed for the private sector. ${ }^{26} \mathrm{~A}$ Federal Advisory Council on Occupational Safety and Health was established by the Order to advise the Secretary of Labor. ${ }^{27}$ OSHA provides guidance to the agencies, evaluates their safety and health efforts, collects job injury and illness statistics, and reports annually to the President. As a result of promotional activities under OSHA's aegis thus far, the injury incidence rate among federal civilian employees has decreased materially.

\section{E. The Role of Workmen's Compensation}

The final expression of the stimulative effect of the Act is the growing improvement in state workmen's compensation benefits. Although OSHA does not administer the federal government's activities in this field, the problem of workmen's compensation is inextricably intertwined with the activities delegated to OSHA by the Act. The National Commission on State Workmen's Compensation Laws, which was created by the Occupational Safety and Health Act of 1970, submitted a report in 1972 proposing more than eighty improvements in state laws designed to compensate victims of industrial accidents

\footnotetext{
${ }^{23}$ Approved plans are those of Alaska, California, Colorado, Connecticut, Hawaii, Illinois, Indiana, Iowa, Kentucky, Maryland, Michigan, Minnesota, Montana, Nevada, New Jersey, New York, North Carolina, Oregon, South Carolina, Tennessee, Utah, Vermont, Virgin Islands, Washington, Wisconsin, and Wyoming. States that have withdrawn proposed plans are Georgia, New Hampshire, North Dakota, and Pennsylvania. Plans have not been submitted by Kansas, Louisiana, Nebraska, Ohio, South Dakota, and the Trust Territories of the Pacific. OSHA has initiated action to reject the Virginia plan.

${ }^{24}$ Occ. Safety \& Health Act $\$ 3(5), 29$ U.S.C. $\$ 652(5)(1970)$.

${ }^{25} I d . \$ 19(\mathrm{a}), 29$ U.S.C. $\$ 668(\mathrm{a})$.

${ }^{26}$ Exec. Order No. 11612,3 C.F.R. 343 (1973).

${ }_{27}$ The Council is composed of fifteen members and includes representatives of federal agencies and labor organizations representing personnel of these agencies.
} 
or illness. ${ }^{28}$ These recommendations dealt with employee coverage, full medical and rehabilitative services, adequate weekly benefit levels, and elimination of arbitrary limits on the total amount or duration of benefits. The states were to be given an opportunity to improve their laws, but compliance with the essential recommendations of the Commission was to be evaluated in 1975 . The Commission asked Congress to take action if the recommendations were not implemented by that time.

As a result of these recommendations, a number of states have completed comprehensive revisions of their workmen's compensation laws. Five have changed their programs from elective to compulsory in nature. Exemptions of small firms based on number of employees have been eliminated or reduced in eight, and several have extended their coverage of agricultural workers. Full coverage of occupational disease was provided for the first time in five states. Finally, most states have liberalized their maximum weekly benefit provisions, and several have reduced the waiting period before benefits become payable. ${ }^{29}$

\section{ConcLusion}

The provisions of the Occupational Safety and Health Act of 1970 and the manner in which they have been implemented indicate that the federal government is serving as a catalyst in developing public awareness of the problem of workplace hazards as well as methods for its solution. The key question for carrying out this legislation is: how can the potential of a hazard-free work environment be maximized without creating an overbearing federal presence? The approach described throughout this paper provides the Administration's answer.

If the federal government were to view its role as that of an enforcement mechanism alone, those to be protected by such inclusive legislation would be ill-served. The tragedy of on-the-job deaths, injuries, and illnesses is too complex to be eliminated through inspections, citations, and penalties alone. An adequate solution requires a multifaceted approach involving enforcement, research, voluntary compliance, and assistance from the states. Only through the involvement of federal and state governments, private industry, the labor movement, occupational safety and health professionals, the medical profession, and every other segment of society affected by this problem can it be placed in its proper frame of reference-a complex, diversely-manifested social pathology with myriad causes.

\footnotetext{
${ }^{28}$ See National Commission on State Workmen's Compensation Laws, The Report of the National Commission on State Workmen's Compensation Laws 13-27 (1972).

${ }^{29}$ Johnson, Changes in Workmen's Compensation Laws in 1973, 97 Monthly LAB. Rev., Jan. 1974 , at 32 .
} 